\title{
PENGARUH KOMPENSASI DAN PENGEMBANGAN KARIR TERHADAP QUALITY OF WORK LIFE PADA PERAWAT RUMAH SAKIT DI KOTA YOGYAKARTA
}

\author{
Yati Suhartini \\ Universitas PGRI Yogyakarta \\ e-mail: yati.suhartini@yahoo.com
}

\begin{abstract}
The research was conducted with the aim of knowing the influence of compensation and career development toward the quality of work life in the hospital nurses in Kota Yogyakarta. The sample of this research is 75 people, taken from a population of 284 people. Data was collected by applying questionnaires, analized by using multiple linier regression,and processed with the SPSS application program. Based on the result of data analysis, it was showed that the two independent variables, namely compensation $\left(X_{1}\right)$, and career development $\left(X_{2}\right)$,) influenced partially or simultaneously on quality of work life $(Y)$, thus partially or simultaneously supporting the 3 hypotheses. Those were indicated by the value of regression coefficient and the significant level of each factor which are 0.227 and 0.009; 0,546 and 0,000, respectively. Likewise, the value of $F$ amounting to 43,100 with the significance level of 0,000, whereas adjusted $R^{2}$ counting to 0,532. Furthermore, career development indicates as the dominant variable that influences on the quality of work life.
\end{abstract}

Keyword : compensation, career development, and the quality of work life

\begin{abstract}
Abstrak
Penelitian ini dilakukan dengan tujuan untuk mengetahui pengaruh kompensasi dan pengembangan karir terhadap quality of work life pada perawat rumah sakit di KotaYogyakarta. Sampel penelitian ini sebanyak 75 orang yang diambil dari populasi sebanyak 284 orang. Pengumpulan data dilakukan dengan menggunakan kuesioner, dianalisis dengan menggunakan regresi linier berganda, dan diolah dengan program aplikasi SPSS. Berdasarkan hasil analisis data menunjukkan bahwa dua variabel independen yaitu kompensasi $\left(\mathrm{X}_{1}\right)$, dan pengembangan karir $\left(\mathrm{X}_{2}\right)$, berpengaruh secara parsial maupun simultan terhadap quality of work life atau kualitas kehidupan kerja (Y), sehingga secara parsial maupun simultan mendukung 3 hipotesis. Hal tersebut ditunjukkan dengan nilai koefisien regresi dan tingkat signifikansi masing-masing faktor yaitu 0,227 dan 0,009; 0,546 dan 0,000. Begitu juga dengan nilai F-hitung sebesar 43,100 dengan taraf signifikansi 0,000, sedangkan nilai adjusted R2 sebesar 0,579. Selanjutnya pengembangan karir menunjukkan sebagai variabel dominan yang berpengaruh terhadap kualitas kehidupan kerja
\end{abstract}

Kata kunci : kompensasi, pengembangan karir, dan quality of work life 


\section{PENDAHULUAN}

\section{Latar Belakang}

Salah satu sumber daya yang paling besar serta mempunyai peranan penting dalam pencapaian tujuan rumah sakit dan kualitas layanan rumah sakit adalah perawat. Hal ini terkait dengan keberadaan perawat yang bertugas selama 24 jam melayani pasien dan jumlah perawat yang mendominasi tenaga kesehatan di rumah sakit, yaitu sekitar $40-60$ \% (Swansburg, 2000; PPNI, 2005). Potter dan Perry (2005) menyatakan bahwa keberhasilan pelayanan rumah sakit sangat bergantung pada partisipasi perawat dalam memberikan perawatan yang berkualitas bagi pasien. Oleh sebab itu, perawat sebagai tenaga kesehatan terbesar sudah seharusnya memiliki kualitas kehidupan kerja atau quality of work life (QWL) yang baik sehingga dapat memberikan pelayanan yang berkualitas pada pasien (Moradi et al., 2014).

Pentingnya quality of work life pada perawat tersebut sudah semestinya menjadi perhatian juga pada rumah sakit - rumah sakit yang menjadi tempat penelitian ini, yaitu rumah sakit tipe D di Kota Yogyakarta yang bekerjasama dengan Badan Penyelenggara Jaminan Sosial (BPJS) Kesehatan. (Dinas Kesehatan DIY, Online) Rumah sakit tipe D tersebut sebagai Fasilitas Kesehatan Tingkat Pertama (FKTP), merupakan ujung tombak pelayanan kesehatan di rumah sakit dan memiliki fungsi sebagai kontak pertama dari peserta BPJS Kesehatan sehingga berdampak besar bagi peningkatan status kesehatan masyarakat. Luthans (2006) menyatakan bahwa quality of work life mempunyai peran yang penting terhadap jalannya aktivitas kerja, dimana para pimpinan dan bawahan harus dapat menentukan dan melaksanakan kegiatan dengan adanya kesepakatan dalam menjalankan kegiatan pekerjaan. Sedangkan faktor-faktor yang mempengaruhi QWL menurut Cascio (2010) adalah: 1) partisipasi karyawan, 2) pengembangan karir, 3) penyelesaian konflik, 4) komunikasi, 5) kesehatan kerja, 6) keselamatan kerja, 7) keamanan kerja, 8) kompensasi yang layak, dan 9) kebanggaan. Fokus penelitian ini mempelajari dua faktor yang mempengaruhi QWL, yaitu faktor kompensasi dan faktor pengembangan karir.

Salah satu alasan manusia bekerja karena ingin memperoleh uang untuk memenuhi kebutuhan hidupnya. Untuk itulah seorang karyawan mulai menghargai kerja kerasnya, karena kompensasi mencerminkan ukuran karya mereka diantara para karyawan itu sendiri, keluarga dan masyarakat. Kompensasi juga merupakan salah satu cara manajemen untuk meningkatkan produktifitas kerja, motivasi kerja, prestasi kerja dan kepuasan kerja karyawan (Nawawi, 2011). Dengan kata lain, kompensasi merupakan salah satu cara untuk menumbuhkan quality of work life yang baik bagi karyawan (Cascio,WF., 2010). Hasil wawancara dengan beberapa perawat mengatakan bahwa rumah sakit terus menuntut perawat untuk selalu meningkatkan kinerjanya guna memperbaiki mutu keperawatan, namun hal itu tidak sebanding dengan peningkatan kualitas kehidupan kerja perawat. Misalnya, perawat merasa gaji yang mereka terima belum sesuai dengan kerja yang telah mereka lakukan. Selain itu, perawat merasa insentif yang diberikan oleh rumah sakit belum sesuai dengan harapan mereka. Keluhan tersebut menunjukkan adanya indikasi kurangnya quality of 
work life pada perawat di rumah sakit yang diteliti.

Selain faktor kompensasi, yang menjadi fokus penelitian ini yaitu masalah pengembangan karir perawat. Pengembangan karier merupakan fungsi manajemen personalia yang sangat penting dan perlu diketahui oleh setiap karyawan. Dalam pelaksanaan tanggung jawab pengembangan karir seharusnya diterima bukan sekedar promosi ke jabatan yang lebih tinggi, tetapi sukses karir yang dimaksudkan seorang karyawan mengalami kemajuan dalam bekerja, berupa perasaan puas dalam setiap jabatan yang dipercayakan oleh organisasi (Moekijat, 2010). Dengan demikian pengembangan karir akan meningkatkan kualitas kerja karyawan, dan karyawan akan berusaha mengontrol karirnya serta mencapai karir yang lebih baik sehingga ia akan terus berprestasi dan memperoleh kepuasan kerja. Kondisi kerja seperti itulah yang mendorng memunculkan quality of work life yang baik bagi karyawan (Cascio,2010). Hasil wawancara dengan beberapa perawat, diperoleh keluhan bahwa belum adanya gambaran yang jelas tentang jenjang karir yang bisa dicapai bila karyawan menampilkan kinerja yang memuaskan, serta kesempatan pengembangan karir yang belum merata. Hal ini mengindikasikan adanya permasalahan dalam pengembangan karir perawat dan perlunya peningkatan manajemen karir pada rumah sakit yang diteliti tersebut. Berdasarkan latar belakamg
masalah tersebut mengindikasikan bahwa quality of work life pada perawat yang diamati masih perlu ditingkatkan, maka salah satu aspek yang menarik untuk dikaji secara empirik adalah : apakah kompensasi dan pengembangan karir mempunyai pengaruh terhadap quality of work life pada perawat rumah sakit di Kota Yogyakarta.

\section{Rumusan Masalah}

Dari latar belakang masalah tersebut di atas, maka rumusan masalah dalam penelitian ini adalah : 1) Apakah kompensasi berpengaruh terhadap quality of work life pada perawat rumah sakit di Kota Yogyakarta ? ; 2) Apakah pengembangan karir berpengaruh terhadap quality of work life pada perawat rumah sakit di Kota Yogyakarta ? ; 3) Apakah kompensasi dan pengembangan karir secara simultan berpengaruh terhadap quality of work life pada perawat rumah sakit di Kota Yogyakarta?

\section{Tujuan Penelitian}

Tujuan penelitian merupakan sasaran yang ingin dicapai dalam sebuah penelitian. Adapun tujuan penelitian ini adalah : 1) Untuk mengetahui pengaruh kompensasi terhadap quality of work life pada perawat rumah sakit di Kota Yogyakarta ? ; 2) Untuk mengetahui pengaruh pengembangan karir terhadap quality of work life pada perawat rumah sakit di Kota Yogyakarta ? ; 3) Untuk mengetahui pengaruh kompensasi dan pengembangan karir secara simultan terhadap quality of work life pada perawat rumah sakit di Kota Yogyakarta?

\section{Manfaat Penelitian}

Bagi rumah sakit yang diteliti, hasil penelitian ini akan memberikan informasi empiris tentang pengaruh faktor kompensasi dan pengembangan karir terhadap quality of work life pada perawat, sehingga informasi tersebut bisa menjadi masukan untuk perbaikan. 
Bagi peneliti lain yang berminat dalam penelitian yang sama, hasil penelitian ini bisa digunakan sebagai referensi untuk melakukan penelitian lebih lanjut.

\section{KAJIAN TEORI}

\section{Qality Of Work Life}

- Pengertian Quality Of Work Life Pengertian Quality of Work Life (QWL) atau Kualitas Kehidupan Kerja yang banyak digunakan adalah pengertian yang berasal dari Cascio. Hal tersebut dikarenakan Cascio dipandang sebagai pelopor dari perkembangan teori Quality Of Work Life itu sendiri. Menurut Cascio, W.F. (2010), menyatakan bahwa terdapat dua cara dalam menjelaskan quality of work life yaitu: pertama, quality of work life dipandang sebagai sekumpulan persepsi karyawan mengenai rasa aman dalam bekerja, kepuasan kerja, dan kondisi untuk dapat tumbuh dan berkembang sebagai manusia. Kedua, quality of work life dipandang sebagai sekumpulan sasaran yang ingin dicapai melalui kebijakan organisasi seperti: kondisi kerja yang aman, keterlibatan kerja, kebijakan pengembangan karir, kompensasi yang adil dan lain-lain.

Selanjutnya, Flippo (2013) mendefinisikan quality of work life sebagai setiap kegiatan perbaikan yang terjadi dalam suatu organisasi untuk meningkatkan efektivitas organisasi yang lebih besar melalui peningkatan martabat dan pertumbuhan manusia. Nawawi (2011) menyatakan quality of work life atau QWL merupakan program yang mencakup cara untuk menciptakan rasa aman dan kepuasan dalam bekerja, agar sumber daya manusia di dalam perusahaan menjadi kompetitif.
Dari pengertian tersebut berarti bahwa quality of work life adalah persepsi-persepsi karyawan bahwa mereka ingin merasa aman, puas, memiliki kehidupan yang seimbang antara rumah dan pekerjaan, serta mendapat kesempatan untuk tumbuh dan berkembang selayaknya manusia

\section{- Faktor-faktor Yang mempengaruhi Quality of Work Life}

Peningkatkan kualitas

kehidupan kerja karyawan dapat dilakukan dengan memperhatikan faktor-faktor yang mempengaruhinya. Faktor-faktor yang mempengaruhi dalam quality of work $l$

ife menurut Cascio (2010) adalah: 1) komunikasi, 2) penyelesaian konflik, 3) pengembangan karir (career development), 4) partisipasi karyawan (employee participation), 5) kebanggaan (pride), 6) kompensasi yang seimbang (equitable compensation), 7) keselamatan lingkungan, 8) keamanan kerja (job security), dan 9) kesehatan kerja (wellness)

Selanjutnya fator-faktor QWL dari Casio tersebut dikembangkan penjelasannya oleh Nawawi, Hadari (2011) sebagai pedoman program peningkatan kualitas kehidupan kerja atau quality of work life, sebagai berikut:

1) Komunikasi. Di setiap lingkungan organisasi atau perusahaan, karyawan memerlukan komunikasi yang terbuka dalam batas-batas wewenang dan tanggung jawab masing-masing. Dengan komunikasi yang lancar maka karyawan akan mendapat informasi-informasi penting secara tepat dan juga dapat menimbulkan rasa puas serta merupakan motivasi kerja yang positif.

2) Penyelesaian konflik. Di lingkungan suatu perusahaan, 
setiap karyawan memiliki kesempatan untuk memberikan sumbangan dalam memecahkan konflik di perusahaan maupun konflik antar karyawan secara terbuka, jujur dan adil. Kondisi tersebut sangat berpengaruh pada loyalitas dan dedikasi serta motivasi karyawan.

3) Pengembangan karier. Di lingkungan suatu perusahaan, setiap karyawan memerlukan kejelasan tentang pengembangan karier mereka dalam menghadapi masa depan. Untuk itu dapat ditempuh melalui penawaran kenaikan jabatan, memberi kesempatan mengikuti pelatihan dan penilaian karya.

4) Partisipasi karyawan. Di lingkungan suatu perusahaan, setiap karyawan perlu diikutsertakan dalam proses pengambilan keputusan dan pelaksanaan pekerjaan sesuai dengan posisi, kewenangan dan jabatan masing-masing.

5) Kebanggaan. Di lingkungan suatu perusahaan, setiap karyawan perlu dibina dan dikembangkan perasaan bangganya pada tempatnya bekerja, termasuk juga pada pekerjaan atau jabatannya. Untuk keperluan itu perusahaan berkepentingan menciptakan dan mengembangkan identitas yang dapat menimbulkan rasa bangga karyawan pada perusahaan. Dalam bentuk yang sederhana dapat dilakukan melalui logo, lambang, jaket perusahaan dan lain-lain.

6) Kompensasi yang seimbang. Di lingkungan suatu perusahaan, setiap karyawan harus memperoleh kompensasi yang adil/wajar dan mencukupi. Untuk itu diperlukan kemampuan menyusun dan menyelenggarakan sistem dan struktur pemberian kompensasi langsung dan tidak langsung (pemberian upah dasar dan berbagai keuntungan/manfaat) yang kompetitif dan dapat mensejahterakan kehidupan karyawan sesuai posisi/jabatannya di perusahaan dan status ekonominya di masyarakat.

7) Keselamatan Lingkungan. Di lingkungan suatu perusahaan, setiap karyawan memerlukan keamanan lingkungan kerja. Untuk itu perusahaan berkewajiban menciptakan dan mengembangkan serta memberi jaminan lingkungan kerja yang aman.

8) Keamanan kerja. Di lingkungan suatu perusahaan, setiap 8) karyawan memerlukan rasa aman atau jaminan kelangsungan pekerjaannya. Untuk itu perusahaan perlu berusaha menghindari pemberhentian sementara para karyawan, menjadikannya sebagai pekerja/karyawan tetap dengan memiliki tugas-tugas reguler dan memiliki program yang teratur dalam memberikan kesempatan karyawan untuk mengundurkan diri, terutama melalui pengaturan pensiun.

9) Kesehatan kerja. Di lingkungan suatu perusahaan, setiap karyawan memerlukan perhatian terhadap pemeliharaan kesehataannya agar dapat bekerja secara efektif, efisien dan produktif. Untuk itu perusahaan dapat mendirikan dan menyelenggarakan program pemeliharaan kesehatan, program rekreasi dan program konseling/penyuluhan bagi karyawan.

\section{Kompensasi}

\section{- Pengertian Kompensasi}

Kompensasi adalah semua pendapatan yang berbentuk uang, barang langsung atau tidak langsung yang diterima karyawan sebagai imbalan jasa yang diberikan kepada 
perusahaan (Hasibuan, 2017). Menurut Marwansyah (2014), kompensasi adalah penghargaan atau imbalan langsung maupun tidak langsung, finansial maupun nonfinansial yang adil dan layak kepada karyawan, sebagai balasan atas kontribusi terhadap pencapaian tujuan organisasi. Selanjutnya, menurut Handoko (2014) kompensasi ialah segala sesuatu yang diterima karyawan sebagai balas jasa untuk kerja mereka yang berupa upah /gaji pokok yang pembayarannya diterima karyawan secara bulanan, mingguan ataupun setiap jam sebagai hasil dari pekerjaan mereka.

- Tujuan pemberian kompensasi menurut Hasibuan (2017) antara lain:

1) Ikatan kerja sama. Dengan pemberian kompensasi terjalinlah kerja sama formal antara majikan dengan karyawan.

2) Kepuasan kerja. Dengan balas jasa, karyawan akan dapat memenuhi kebutuhan-kebutuhan fisik, sosial dan egoistiknya sehingga memperoleh kepuasan kerja dan jabatannya.

3) Pengadaan efektif. Jika kompensasi ditetapkan cukup besar,pengadaan karyawan yang qualified untuk perusahaan akan lebih mudah.

4) Motivasi. Jika balas jasa yang diberikan cukup besar, manajer akan mudah memotivasi bawahannya.

5) Stabilitas karyawan. Dengan program kompensasi atas prinsip adil dan layak serta eksternal konsistensi yang kompentatif maka stabilitas karyawan lebih terjamin karena turn-over relatif kecil.

6) Disiplin. Dengan pemberian balas jasa yang cukup besar maka disiplin karyawan semakin baik.
7) Pengaruh serikat buruh. Dengan program kompensasi yang baik pengaruh serikat buruh dapat dihindarkan dan karyawan akan berkonsentrasi pada pekerjaannya

8) Pengaruh pemerintah. Jika kompensasi sesuai dengan undangundang perburuhan yang berlaku maka intervensi pemerintahan dapat dihindarkan.

\section{Pengembangan Karir.}

Karir adalah keseluruhan jabatan/pekerjaan/posisi yang dapat diduduki seseorang selama kehidupan kerjanya dalam organisasi atau dalam beberapa organisasi. Pengembangan adalah sesuatu yang melampaui pekerjaan karyawan dan membantu mereka menyiapkan berbagai pekerjaan dimasa mendatang. Jadi, pengembangan karir adalah proses peningkatan kemampuan kerja individu yang dicapai dalam rangka mencapai karir yang diinginkan (Handoko, 2014), Menurut

Mangkunegara (2013), pengembangan karir adalah aktifitas kepegawaian yang membantu para karyawan merencanakan karir masa depan mereka diperusahaan agar perusahaan dan karyawan yang bersangkutan dapat mengembangan diri secara maksimum Selanjutnya, menurut Mondy (2008), pengembangan karir adalah pendekatan formal yang digunakan organisasi untuk memastikan bahwa orang dengan kualifikasi dan pengalaman yang tepat tersedia jika dibutuhkan

Pengembangan karier perlu dipahami dua proses, yaitu bagaimana seseorang merencanakan dan mengimplementasikan tujuan kariernya sendiri (career planing) dan bagaimana institusi merancang dan mengimplementasikan program pengembangan kariernya (career management) Bambang Wahyudi (2002) 


\section{Tujuan Pengembangan Karir}

Menurut Sutrisno (2009), pengembangan karir memiliki tujuan sebagai berikut.

1) Memberikan kepastian arah karir karyawan dalam kiprahnya di organisasi.

2) Meningkatkan daya tarik organisasi/institusi bagi para karyawan berkualitas.

3) Memudahkan manajemen dalam menyelenggarakan programprogram pengembangan sumber daya manusia.

4) Memudahkan administrasi kepegawaian, khususnya dalam melakukan administrasi pergerakan karyawan seperti promosi, rotasi ataupun demosi

\section{Penelitian Terdahulu}

1) Pratama,Yuda Muchti (2016) melakukan penelitian yang berjudul "Analisis Kualitas Kehidupan Kerja Perawat Pelaksana Di Rumah Sakit Ptrtri Hijau Medan" Jenis penelitian ini adalah deskriptif dengan metode survei yang bertujuan untuk menganalisis kualitas kehidupan kerja yaitu keterlibatan karyawan, pengembangan karir, pemecahan masalah, komunikasi, fasilitas yang tersedia, keamanan kerja, keselamatan kerja, kompensasi yang seimbang, dan kebanggaan institusi. Subjek penelitian ini adalah 79 perawat. Analisis data dilakukan dengan menggunakan analisis univariat. Kesimpulan dari penelitian ini adalah variabel dengan kategori baik adalah komunikasi, penyelesaian masalah, keterlibatan karyawan, dan rasa bangga terhadap institusi. Sedangkan kategori kurang baik adalah keamanan kerja,keselamatan lingkungan kerja, pengembangan karir, kompensasi dan fasilitas yang tersedia.

2) Anisah, (2017) melakukan penelitian yang berjudul "Evaluasi Faktor-Faktor

Yang
Mempengaruhi Quality Of Work Life" (Studi Kasus PT.Pelabuhan Indonesia II Persero). Penelitian ini bertujuan untuk mengevaluasi faktor-faktor yang mempengaruhi Kualitas Kehidupan Kerja di Pelabuhan PT Indonesia II (Persero), Penelitian ini adalah penelitian kuantitatif. Data dianalisis dengan statistik untuk menentukan apakah generalisasi prediktif dari teori-teori benar. Hasil penelitian ini diketahui bahwa ada enam variabel berpengaruh positif dan signifikan terhadap quality of work life, yaitu imbalan yang memadai, kondisi dan lingkungan pekerjaan yang aman dan sehat, kesempatan untuk menggunakan

dan mengembangkan kemampuan, kesempatan berkembang dan keamanan berkarya dimasa depan, keseimbangan antara kehidupan kekaryaan dan kehidupan pribadi, dan relevansi social kehidupan kekaryaan

3) Rohayati, Teti. Dkk (2020), melakukan penelitian yang berjudul "Dampak Perubahan Pemberdayaan dan Pengembangan Karir Terhadap Kualitas Kehidupan Kerja Pada PT Reasuransi Indonesia Utama (Persero)". Metode analisis yang digunakan untuk menjawab hipotesis yaitu menggunakan SEMPLS dengan program SmartPLS. Hasil penelitian ini menunjukkan bahwa terdapat pengaruh langsung dan positif pemberdayaan terhadap pengembangan karir; terdapat pengaruh langsung dan positif pemberdayaan dan pengembangan karir terhadap kualitas kerja karyawan; dan pemberdayaan berpengaruh tidak langsung terhadap kualitas kerja karyawan melalui pengembangan karir. 
Pengaruh langsung pengembangan karir terhadap kualitas kehidupan pemberdayaan terhadap kualitas kerja lebih besar dari pada pengaruh tidak langsung

kehidupan kerja melalui pengembangan karir.

\section{Kerangka Berpikir}

Berdasarkan kajian teori dan tinjauan empiris penelitian terdahulu tentang pengaruh kompensai dan pengembangan karir terhadap quality of work life karyawan, maka kerangka berpikir penelitian ini sebagai berikut :

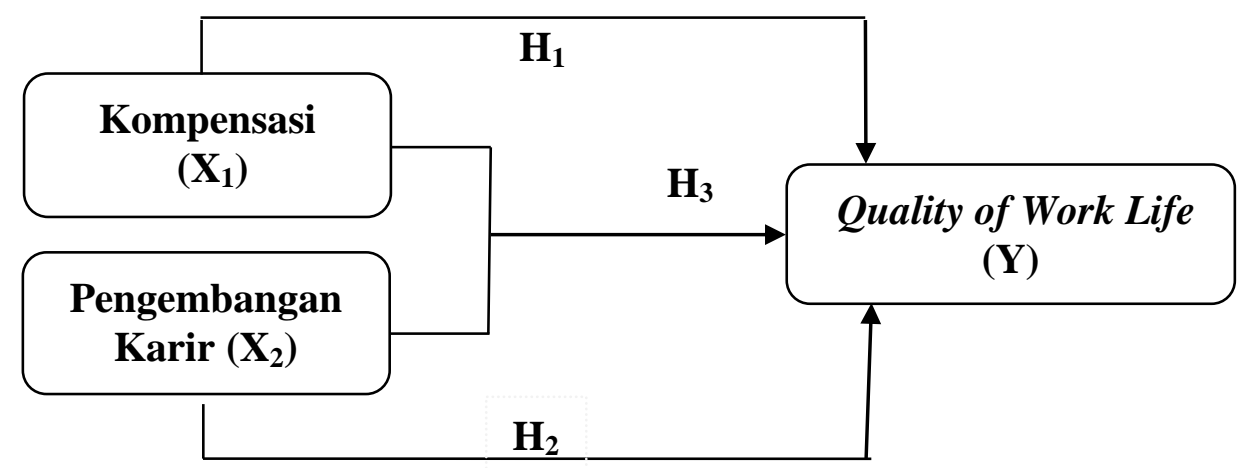

Gambar 1. Kerangka Berpikir

\section{Hipotesis Penelitian}

Berdasarkan latar belakang, kajian teori dan empiris penelitian terdahulu serta kerangka berpikir, maka hipotesis penelitian ini adalah : variabel independen terhadap quality of work life sebagai variabel dependen.

\section{Waktu dan Tempat Penelitian}

\section{Penelitian dilakukan}

Diduga kompensasi berpengaruh pos work life pada perawat rumah sakit di Kulan Agustus-September 2020 pada

rumah ogxakarta

$\mathrm{H}_{2}$ : Diduga pengembangan karir berpengaruh positif dan sionifikan terhadap quality of work life pada perawat rumah sakit di Kota Yogyakapta

$\mathrm{H}_{3}$ : Diduga kompensasi dan pengembangan Karir secara simultan kerpengaruh signifikan terhadap quality of work life pada perawat rumah sakit di Kota Yogyakarta

\section{METODOLOGI PENELITIAN}

\section{Jenis Penelitian}

Penelitian ini merupakan jenis penelitian kuantitatif dan permasalahan yang akan diuji adalah permasalahan asosiasif dengan bentuk hubungan kausal, yaitu hubungan yang bersifat sebab akibat (Sugiyono, 2016). Jadi, hubungan kausal memiliki variabel independen (yang mempengaruhi) dan variabel dependen (yang dipengaruhi). Hal ini berarti penelitian berfokus pada pengaruh kompensasi dan pengembangan karir sebagai

\section{Populasi dan Sampel}

Populasi penelitian ini adalah perawat yang bekerja pada rumah sakit tipe D di wilayah Kota Yogyakarta yang bekerjasama dengan Badan Penyelenggara Jaminan Sosial (BPJS) Kesehatan sebanyak 284 orang. (Badan PPSDM Kesehatan, Informasi Kesehatan, Kementrian Kesehatan Republik, Online)

$$
\text { Sedangkan responden }
$$

penelitian diambil dengan menggunakan metode proposional random sampling. Untuk menentukan ukuran sampel dari populasi digunakan rumus Slovin dikutip oleh Umar (2013) sebagai berikut : 


$$
\mathrm{n}=\mathrm{N} /\left(1+\mathrm{N} \cdot \mathrm{e}^{2}\right)
$$

Keterangan:

$\mathrm{n}=$ sampel

$\mathrm{N}=$ jumlah populasi

$\mathrm{e}=$ tingkat kesalahan pengambilan sampel Mitapka

keterbatasan waktu dan biaya, dan masih dapyatmgenggunakammampesn gdowinn

(Sevilla et. al., 2007)

Berdasarkan hasil perhitungan dengan menggunakan rumus slovin diperoleh sample penelitian sebanyak 75 (pembulatan) responden penelitian

\section{Variabel Penelitian, Definisi Operasional, dan Indikator}

Variabel penelitian ini meliputi variabel independen yaitu kompensasi $\left(\mathrm{X}_{1}\right)$, dan pengembangan karir $\left(\mathrm{X}_{2}\right)$; variabel dependen yaitu quality of work life (Y).

- Quality Of Work Life (Y)

Quality of work life (QWL) atau kualitas kehidupan kerja merupakan ungkapan umum dari perasaan pekerja tentang setiap dimensi pekerjaannya yang meliputi penghargaan dan manfaat ekonomi, keamanan, kondisi kerja, hubungan organisasi dan interpersonal serta makna intrinsiknya dalam kehidupan seseorang.

Indikator quality of work life mengacu pada indikator yang dikembangkan oleh Porkiani. et al . (2011), yaitu sebagai berikut :

1) Keamanan kerja

Merupakan harapan-harapan karyawan terhadap keberlangsungan pekerjaannya. Keamanan kerja mencakup hal-hal seperti ada atau tidaknya kesempatan promosi, kondisi pekerjaan umumnya dan kesempatan karir jangka panjang.

2) Keadilan dan kesetaraan Merupakan sebuah konsep luas yang menganggap bahwa individu harus mendapatkan perlakuan yang adil dan setara dalam semua tindakan yang berhubungan dengan pekerjaan

3) Pendapatan gaji dan tunjangan bagaimana dan mengapa orang-orang memilih untuk bekerja disebuah organisasi daripada organisasi yang lain.

4) Peningkatan keterampilan dan kesempatan

Merupakan proses dimana seseorang mendapatkan peluang untuk meningkatkan kapabilitas untuk membantu pencapaian tujuan organisasional.

5) Partisipasi karyawan dalam mengambil keputusan

Merupakan pemberian kewenangan dan tanggung jawab kepada karyawan untuk mengambil keputusan tentang pekerjaan mereka tanpa harus pengawasan manajerial sebagaimana biasanya

- Kompensasi $\left(\mathrm{X}_{1}\right)$

Kompensasi adalah semua pendapatan yang berbentuk uang, barang langsung ataupun tidak langsung yang diterima karyawan sebagai imbalan atas jasa yang diberikan pada perusahaan.

Indikator kompensasi menurut Simamora (2015):

1) Upah dan gaji yang adil sesuai dengan pekerjaan

Upah biasanya berhubungan dengan tarif gaji per jam. Upah merupakan basis bayaran yang kerapkali digunakan bagi pekerjapekerja produksi dan pemeliharaan. Gaji umumnya berlaku untuk tarif bayaran melewati persetujuan dan 
mingguan, bulanan, atau tahunan.

2) Insentif yang sesuai dengan pengorbanan.

Insentif adalah tambahan kompensasi di luar gaji atau upah yang diberikan oleh organisasi.

3) Tunjangan yang sesuai dengan harapan.

Contoh tunjangan adalah asuransi kesehatan dan jiwa, liburan yang ditanggung perusahaan, program pension, dan tunjangan lainnya yang berkaitan dengan hubungan kepegawaian.

4) Fasilitas yang memaadai.

Pada umumnya berhubungan dengan kenikmatan seperti mobil perusahaan, akses ke pesawat perusahaan, tempat parki khusus, dan kenikmatan perlakuan khus yang diperoleh karyawan.

- Pengembangan Karir

Pengembangan karir adalah suatu proses berkesinambungan yang dilalui individu melalui upayaupaya pribadi dalam rangka mewujudkan tujuan perencanaan kariernya yang disesuaikan dengan kondisi organisasi.

Indikator pengembangan karir menurut Marihot (2010), yaitu :

1) Perhatian pada pembinaan karir pegawai.

2) Pemberian kesempatan dalam pelatihan.

3) Sistim penilaian yang obyektif

4) Adanya ruang konsultasi karir.

5) Adanya kesempatan promosi

\section{Teknik Pengumpulan Data dan Pengukuran}

Teknik pengumpulan data dalam penelitian ini menggunakan kuesioner yang terdiri atas pernyataan yang dibuat sesuai dengan indikator dari masing-masing variabel.
Kuesioner diberikan kepada responden penelitian untuk dijawab. Selain itu, pengumpulan data juga dilakukan melalui tanya jawab langsung antara peneliti dan narasumber untuk menggali permasalahan yang ingin diteliti.

Pengukuran data menggunakan skala likert yang terdiri dari pilihan jawaban dan skor, seperti berikut: Sangat Setuju=SS (skor 5), Setuju $=S$ (skor 4 ), Netral=N (skor 3 ), Tidak Setuju=TS (skor 2), dan Sangat Tidak Setuju=STS (skor 1).

\section{Uji Instrumen}

Sebelum kuesioner digunakan untuk mengumpulkan data penelitian terlebih dahulu dilakukan uji instrumen ke perawat rumah sakit sebanyak 20 orang (Jogiyanto,H.M., 2016). Data yang diperoleh dari kuesioner tersebut diolah dengan bantuan program SPSS versi 22 untuk pengujian validitas dan reliabilitas.

- Uji Validitas

Uji validitas bertujuan untuk mengetahui apakah setiap item pernyataan kuesioner benar-benar mampu mengungkap sesuatu yang seharusnya di ukur. Pengujian validitas menggunakan teknik Pearson Correlation. Butir pertanyaan dikatakan valid jika $r$ hitung > $\mathrm{r}$ tabel dan nilai $\mathrm{p}$ value atau nilai signifikansi hitung kurang dari 0,05 (Sugiyono, 2016). Nilai $r$ tabel untuk $\mathrm{N}=20$ dengan signifikansi 0,05 pada distribusi nilai $\mathrm{r}$ tabel product moment, ditemukan sebesar 0,444.

- Uji Reliabilitas

Kuesioner yang lolos pada uji validitas, selanjutnya dilakukan pengujian reliabilitas, yang bertujuan untuk menguji konsistensi hasil jika alat ukur digunakan untuk pengukuran berulang. Pengujian reliabilitas dilakukan dengan uji koefisien Cronbach Alpha. Kriteria instrumen reliabel adalah ketika nilai koefisien Cronbach Alpha lebih besar 
(>) $\quad 0,60 \quad$ (Sujarweni,V.Wiratna, 2014).

\section{Teknik Analisis Data}

Analisis Regresi Linier Berganda

Data yang terkumpul selanjutnya diolah dengan program aplikasi SPPS dan dianalisis dengan regresi linier berganda. Analisis regresi linier berganda digunakan untuk mengetahui besarnya pengaruh perubahan variabel dependen yang disebabkan oleh perubahan yang terjadi pada variabel independen (Sugiyono, 2016).

Rumus regresi linier berganda $: \mathrm{Y}=\mathrm{a}+$ Keterangan :

$$
\begin{array}{ll}
\mathrm{Y} & : \text { Variabel dependen }=\text { Qualit } \\
\mathrm{X}(1,2) & : \text { Variabel independen }=\text { Ko } \\
\mathrm{a} & \text { : Konstanta dari rata-rata nila } \\
\mathrm{b}(1,2) & \text { : Nilai koefisien regresi }
\end{array}
$$

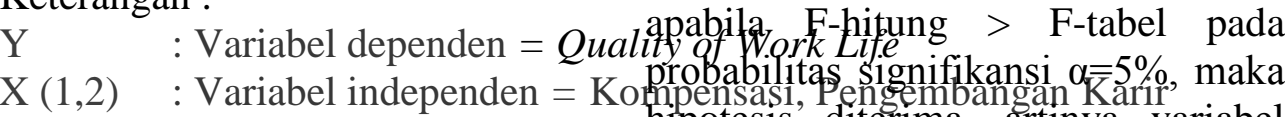

\section{Uji Hipotesis}

\section{- Uji t}

Uji $t$ digunakan untuk mengetahui kebenaran hipotesis, ada tidaknya pengaruh variabel independen $\mathrm{X}$ (Kompensasi dan Pengembangan Karir) secara parsial terhadap variabel dependen $\mathrm{Y}$ (Quality of Work Life). Uji $\mathrm{t}$ dilakukan dengan menggunakan ketentuan : apabila t-hitung > t-tabel pada $\alpha=5 \%$, maka hipotesis diterima, artinya variabel independen secara parsial memiliki pengaruh signifikan terhadap varibel dependen (Sugiyono, 2016)

Untuk nilai $\mathrm{t}$ tabel ditentukan dengan rumus sebagai berikut :

$\mathrm{t}$ tabel $=(\alpha / 2) ; \mathrm{n}-\mathrm{k}-1$ atau df residual, $(\alpha=$ tingkat kepercayaan penelitian $=$ $5 \%, \mathrm{n}=$ jumlah responden $=75, \mathrm{k}=$ jumlah variabel independen $=2$ ). Maka $\mathrm{t}$ tabel $=$ $(0,05 / 2 ; 75-2-1)=(0,025 ; 72)$, diperoleh $\mathrm{t}$ tabel $=1,99346$

\section{- Uji F}

Uji $F$ digunakan untuk mengetahui pengaruh secara simultan variabel independen $X$ (Kompensasi dan Pengembangan Karir) terhadap variabel dependen Y (Quality of Work Life). Atau untuk menguji apakah model regresi yang dibuat baik/signifikan atau tidak baik/non signifikan. Jika model signifikan maka model bisa digunakan untuk prediksi/peramalan, sebaliknya jika non/tidak signifikan maka model regresi tidak bisa digunakan untuk peramalan. Uji $\mathrm{F}$ dilakukan dengan menggunakan ketentuan: apabila F-hitung > F-tabel pada probabilitas signifikansi $\alpha=\overline{\bar{K}} 5 \%$, maka hipotesis diterima, artinya variabel independen secara simultan memiliki pengaruh signifikan terhadap varibel dependen (Sugiyono, 2016)

Untuk nilai $\mathrm{F}$ tabel ditentukan dengan rumus sebagai berikut : $\mathrm{F}$ tabel $=(\mathrm{k} ; \mathrm{n}-\mathrm{k}), \mathrm{k}=$ jumlah variabel independen $=2, \mathrm{n}=$ jumlah responden $=75$ maka diperoleh nilai F tabel $=(2 ; 75-2)=(2 ; 73)=3,12$

\section{- Koefisien Determinasi ( $\mathbf{R}^{2}$ )}

Koefisien determinasi $\left(\mathrm{R}^{2}\right)$ digunakan untuk mengetahui prosentase sumbangan pengaruh dan Pengembangan Karir) secara simultan terhadap variabel dependen Y (Quality of Work Life). Besarnya pengaruh variabel independen $\mathrm{X}$ terhadap variabel dependen $\mathrm{Y}$ dapat diketahui dari koefisien determinasi adjusted $\mathrm{R}^{2}$. Koefisien ini juga menunjukkan seberapa besar prosentase variasi variabel independen yang digunakan dalam model mampu menjelaskan variasi variabel dependen (Sugiyono, 2016). variabel independen $\mathrm{X}$ (Kompensasi 
HASIL PENELITIAN

Hasil Uji Validitas dan Reliabilitas

Uji validitas dilakukan pada

15 butir pernyataan kuesioner, dengan perincian sebagai berikut: kuesioner kompensasi berjumlah $\left(\mathrm{X}_{1}\right) 5$ butir, kuesioner pengembangan karir $\left(\mathrm{X}_{2}\right)$ berjumlah 5 butir, dan kuesioner $Q W L \quad$ berjumlah 5 butir. Dari pengolahan data diperoleh hasil seperti pada tabel 1 , bahwa nilai $\mathrm{r}$ - hitung yang dimiliki tiap butirnya lebih besar dari r-tabel 0,444. Ini berarti, 15 butir pernyaatan kuesioner dapat dikatakan valid (Sugiyono, 2016). Selain itu, nilai $\mathrm{p}$ value atau nilai sig-hitung untuk semua butir pernyataan kurang dari 0,05 . Dengan demikian, semua butir kuesioner dinyatakan valid sebagai alat ukur variabel.

Tabel 1. Hasil Uji Validitas

\begin{tabular}{|l|l|l|l|l|}
\hline Variabel & Item & r-hitung & Sig-hitung & Keterangan \\
\hline \multirow{4}{*}{$\begin{array}{l}\text { Kompensasi } \\
(\mathrm{X} 1)\end{array}$} & $\mathrm{X}_{1.1}$ & 0,671 & 0,001 & Valid \\
\cline { 2 - 5 } & $\mathrm{X}_{1.2}$ & 0,868 & 0,000 & Valid \\
\cline { 2 - 5 } & $\mathrm{X}_{1.3}$ & 0,887 & 0,000 & Valid \\
\cline { 2 - 5 } & $\mathrm{X}_{1.4}$ & 0,861 & 0,000 & Valid \\
\cline { 2 - 5 } Pengembangan & $\mathrm{X}_{1.5}$ & 0,552 & 0,012 & Valid \\
\hline \multirow{4}{*}{ Karir (X2) } & $\mathrm{X}_{2.1}$ & 0.776 & 0,000 & Valid \\
\cline { 2 - 5 } & $\mathrm{X}_{2.2}$ & 0,776 & 0,000 & Valid \\
\cline { 2 - 5 } & $\mathrm{X}_{2.3}$ & 0,842 & 0,000 & Valid \\
\cline { 2 - 5 } & $\mathrm{X}_{2.4}$ & 0.944 & 0,000 & Valid \\
\cline { 2 - 5 } & $\mathrm{X}_{2.5}$ & 0,713 & 0,000 & Valid \\
\hline \multirow{4}{*}{$\begin{array}{l}\text { Wuality of } \\
\text { Work Life (Y) }\end{array}$} & $\mathrm{Y}_{1.1}$ & 0,706 & 0,001 & Valid \\
\cline { 2 - 5 } & $\mathrm{Y}_{1.2}$ & 0,637 & 0,003 & Valid \\
\cline { 2 - 5 } & $\mathrm{Y}_{1.3}$ & 0,763 & 0,000 & Valid \\
\cline { 2 - 5 } & $\mathrm{Y}_{1.4}$ & 0,690 & 0,001 & Valid \\
\cline { 2 - 5 } & $\mathrm{Y}_{1.5}$ & 0,658 & 0,002 & Valid \\
\hline
\end{tabular}

Sumber : Hasil Pengolahan Data Primer 2020

Tabel 2. Hasil Uji Reliabilitas

\begin{tabular}{|l|l|l|c|}
\hline Variabel & Item & Cronbach's Alpha & Keterangan \\
\hline \multirow{4}{*}{$\begin{array}{l}\text { Kompensasi } \\
(\mathrm{X} 1)\end{array}$} & $\mathrm{X}_{1.1}$ & 0,831 & Reliabel \\
\cline { 2 - 4 } & $\mathrm{X}_{1.2}$ & 0,771 & Reliabel \\
\cline { 2 - 4 } & $\mathrm{X}_{1.3}$ & 0,760 & Reliabel \\
\cline { 2 - 4 } & $\mathrm{X}_{1.4}$ & 0,767 & Reliabel \\
\cline { 2 - 4 } & $\mathrm{X}_{1.5}$ & 0,854 & Reliabel \\
\hline \multirow{4}{*}{$\begin{array}{l}\text { Pengembangan } \\
\text { Karir }(\mathrm{X} 2)\end{array}$} & $\mathrm{X}_{2.1}$ & 0,857 & Reliabel \\
\cline { 2 - 4 } & $\mathrm{X}_{2.2}$ & 0,857 & Reliabel \\
\cline { 2 - 4 } & $\mathrm{X}_{2.3}$ & 0,836 & Reliabel \\
\cline { 2 - 4 } & $\mathrm{X}_{2.4}$ & 0,792 & Reliabel \\
\cline { 2 - 4 } & $\mathrm{X}_{2.5}$ & 0,872 & Reliabel \\
\hline \multirow{4}{*}{$\begin{array}{l}\text { Wuality of } \\
\text { Work Life (Y) }\end{array}$} & $\mathrm{Y}_{1.1}$ & 0,694 & Reliabel \\
\cline { 2 - 4 } & $\mathrm{Y}_{1.2}$ & 0,693 & Reliabel \\
\cline { 2 - 4 } & $\mathrm{Y}_{1.3}$ & 0,626 & Reliabel \\
\cline { 2 - 4 } & $\mathrm{Y}_{1.4}$ & 0,677 & \\
\cline { 2 - 4 } & $\mathrm{Y}_{1.5}$ & 0,676 & \\
\hline
\end{tabular}

Sumber : Hasil Pengolahan Data Primer, 2020 
Selanjutnya, semua butir pertanyaan yang valid tersebut diproses uji reliabilitasnya. Hasil uji reliabilitas seperti pada tabel 2 diatas, menunjukkan bahwa nilai Cronbach's Alpha berada lebih besar dari 0,6 . Ini berati butir-butir pertanyaan dalam seluruh variabel penelitian dinyatakan reliabel, maka kuesioner dapat digunakan sebagai alat pengumpul data untuk penelitian.

\section{Hasil Analisis Regresi Linier Berganda}

Hasil analisis regresi linier berganda dengan menggunkaan SPSS Versi 22 diperoleh hasil sebagai berikut:

Tabel 3. Hasil Analisis Regresi Linear Berganda

\begin{tabular}{|l|r|r|r|r|r|}
\hline \multirow{2}{*}{ Model } & \multicolumn{2}{|c|}{$\begin{array}{c}\text { Unstandardized } \\
\text { Coefficients }\end{array}$} & $\begin{array}{c}\text { Standardized } \\
\text { Coefficients }\end{array}$ & \multirow{2}{*}{$\mathrm{t}$} & \multirow{2}{*}{ Sig. } \\
\cline { 2 - 4 } & \multicolumn{1}{|c|}{$\mathrm{B}$} & Std. Error & \multicolumn{1}{|c|}{ Beta } & & \\
\hline 1 (Constant) & 3,901 & 1,448 & & 2,694 & 0,009 \\
Kompensasi & 0,227 & 0,084 & 0,262 & 2,701 & 0,009 \\
Pengembangan Karir & 0,546 & 0,095 & 0,557 & 5,746 & 0,000 \\
\hline
\end{tabular}

a. Dependent Variable: Quality of Work Life

Sumber : Hasil Pengolahan Data Primer, 2020

Berdasarkan tabel 3 diatas, maka dapat diperoleh persamaan regresi sebagai berikut : $\mathrm{Y}=3,901+$ $0,227 X_{1}+0,546 X_{2}$ Penjelasan dari fungsi regresi linier berganda diatas adalah sebagai berikut :

1) Jika $X_{1}$ dan $X_{2}$ bernilai sama dengan nol, maka $Y$ sama dengan 3,901

2) Jika $X_{1}$ (kompensasi ) naik satu satuan, maka Y (quality of work life) akan naik sebesar 0,227 satuan, dengan menganggap $\mathrm{X}_{2}$ (pengembangan karir) tetap.
3) Jika $X_{2}$ (pengembangan karir) naik satu satuan, maka Y (quality of work life) akan naik sebesar 0,546 satuan, dengan menganggap $\quad \mathrm{X}_{1}$ (kompensasi) tetap.

\section{Hasil Uji Hipotesis}

- Uji t (Uji Parsial)

Hasil uji $t$ dalam analisis regresi linier berganda disajikan pada tabel 4 berikut ini :

Tabel 4. Hasil Output Coefficients ${ }^{\mathrm{a}}$ (Uji t)

\begin{tabular}{|l|r|r|}
\hline Model & \multicolumn{1}{|c|}{ t-hitung } & Sig.-hitung \\
\hline 1 (Constant) & 2,694 & .009 \\
Kompensasi & 2,701 & .009 \\
Pengembangan Karir & 5,746 & .000 \\
\hline
\end{tabular}

a. dependen Variable : Quality of Work Life

Sumber : Hasil Pengolahan Data Primer, 2020

Penjelasan hasil uji t yang tercantum pada tabel 4 diatas sebagai berikut :

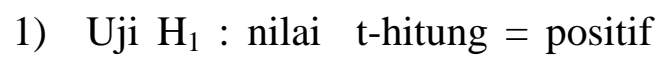
$2,701>$ nilai t-tabel $=1,994$, serta nilai signifikansi $=0,009<$ nilai sig. $\alpha=0,05$, maka berarti 
hipotesis $\mathrm{H}_{1}$ dapat diterima. Dengan demikian dapat diketahui bahwa kompensasi berpengaruh terhadap quality of work life perawat rumah sakit di Kota Yogyakarta secara positif dan signifikan.

2) $\mathrm{Uji}_{2}$ : nilai t-hitung = positif $5,746>$ nilai $\mathrm{t}$-tabel $=1,994$, serta nilai signifikansi $=0,009<$ nilai sig. $\alpha=0,05$, maka berarti hipotesis $\mathrm{H}_{2}$ dapat diterima.
Dengan demikian dapat diketahui bahwa pengembangan karir berpengaruh terhadap quality of work life perawat rumah sakit di Kota Yogyakarta secara positif dan signifikan

\section{- Uji F (Uji Simultan)}

Hasil uji $\mathrm{F}$ dalam analisis regresi linier berganda disajikan pada tabel 5 berikut:

Tabel 5. Hasil Uji ANOVA (Uji F)

\begin{tabular}{|ll|r|r|r|r|r|}
\hline & Model & Sum of Squares & df & Mean Square & F & Sig. \\
\hline 1 & Regression & 310,246 & 2 & 155,123 & 43,100 & $.000^{\mathrm{b}}$ \\
& Residual & 259,140 & 72 & 3,599 & & \\
Total & 569,387 & 74 & & & \\
\hline
\end{tabular}

a. Dependent Variable: Quality of Work Life

b. Predictors: (Constant), Kompensasi, keselamatan kerja

Sumber : Hasil Pengolahan Data Primer, 2020

Berdasarkan tabel 5 hasil uji

ANOVA dapat dijelaskan sebagai berikut :

Nilai F-hitung $=43,1>$ nilai F-tabel $=3,12$, serta nilai signifikansi $=0,000<$ nilai sig. $\alpha=0,05$, maka berarti hipotesis $\mathrm{H} 3$, dapat diterima
Dengan demikian dapat diketahui bahwa kompensasi dan pengembangan karir secara simultan berpengaruh signifikan terhadap quality of work life perawat rumah sakit di Kota Yogyakarta.

\section{- Koefisien Determinasi $\left(\mathbf{R}^{2}\right)$}

Tabel 6. Hasil Analisis Determinasi

\begin{tabular}{|l|r|r|r|r|}
\hline Model & R & R Square & Adjusted R Square & $\begin{array}{r}\text { Std. Error of the } \\
\text { Estimate }\end{array}$ \\
\hline 1 & $0,738^{\mathrm{a}}$ & 0,545 & 0,532 & 1,897 \\
\hline
\end{tabular}

a. Predictors: (Constant) : kompensasi, keselamatan kerja

Sumber : Hasil pengolahan data primer, 2020

Berdasarkan tabel 6 dapat diketahui nilai adjusted $\mathrm{R}$ square sebesar 0,532 , artinya bahwa sumbangan pengaruh variabel independen $\mathrm{X}$ (kompensasi dan pengembangan karir) secara simultan terhadap variabel dependen Y (quality of work life) sebesar 53,2 \% ; sisanya $(46,8 \%)$ dipengaruhi atau dijelaskan oleh variabel lain di luar penelitian ini. 
PEMBAHASAN

1) Pengaruh kompensasi terhadap quality of work life pada perawat rumah sakit di Kota Yogyakarta

Hasil pengujian hipotesis pertama $\left(\mathrm{H}_{1}\right)$ terbukti bahwa kompensasi berpengaruh positif dan signifikan terhadap quality of work life pada perawat rumah sakit di Kota Yogyakarta. Hal ini berarti apabila pemberian kompensasi semakin baik maka quality of work life perawat akan meningkat, dan sebaliknya jika pemberian kompensasinya kurang baik maka akan menurunkan quality of work life perawat. Hasil penelitian ini juga membuktikan bahwa pemberian kompensasi yang dapat dikatakan baik adalah gaji yang didapat perawat sesuai dengan beban kerja, mendapat insentif sesuai dengan prestasi kerja, mendapatkan tunjangan hari raya setiap tahun, dan mendapat jaminan kesehatan selama bekerja. Dengan terpenuhinya kompensasi dengan baik, maka memberikan ketenangan dan kesediaan bagi karyawan untuk bekerja secara optimal sehingga akan berpengaruh positif terhadap quality of work life perawat (Nawawi,Hadari. 2011)

Hasil penelitian ini mendukung beberapa teori yang disampaikan oleh para ahli yang menjadi referensi teoritis dari penelitian ini. Kompensasi yang diberikan kepada pegawai merupakan salah satu faktor dalam mempengaruhi peningkatan quality of work life pada anggota organisasi, karena pada dasarnya kompensasi dapat mendorong dan mempengaruhi semangat kerja yang baik pada karyawan (Cascio, W.F., 2010). Dengan kompensasi, karyawan akan dapat memenuhi kebutuhankebutuhan fisik, sosial dan egoistiknya sehingga memperoleh kepuasan kerja dan jabatannya (Hasibuan, 2017). Untuk itu manajemen perlu memikirkan dan menerapkan kompensasi yang layak dan seusai dengan peraturan yang berlaku.

Hasil penelitian ini juga sesuai dengan penelitian sebelumnya yang dilakukan oleh Anisah (2017) menyatakan bahwa kompensasi berpengaruh positif dan signifikan terhadap quality of work life. Faktor yang dapat mempengaruhi QWL karyawan yaitu pemberian gaji, insentif, jaminan kesehatan, dan tunjangan hari raya. Hal ini dapat disimpulkan bahwa pemberian kompensasi yang baik akan berpengaruh positif terhadap quality of work life karyawan.

\section{2) Pengaruh pengembangan karir terhadap quality of work life pada perawat rumah sakit di Kota Yogyakarta}

Hasil pengujian hipotesis kedua $\left(\mathrm{H}_{2}\right)$ terbukti bahwa pengembangan karir berpengaruh positif dan signifikan terhadap quality of work life pada perawat rumah sakit di Kota Yogyakarta. Hal ini berarti apabila pengembangan karir semakin baik maka quality of work life perawat akan meningkat, dan sebaliknya jika pengembangan karir kurang baik maka akan menurunkan quality of work life perawat. Hasil penelitian ini juga membuktikan bahwa pengembangan karir yang dapat dikatakan baik jika setiap karyawan mendapatkan kejelasan tentang pengembangan karier mereka dalam menghadapi masa depan.Dengan terpenuhinya pengembangan karir dengan baik, maka memberikan ketenangan dan kesediaan bagi karyawan untuk bekerja secara optimal sehingga akan berpengaruh positif terhadap quality 
of work life perawat (Cascio, W.F., 2010).

Hasil penelitian ini mendukung beberapa teori yang disampaikan oleh para ahli yang menjadi referensi teoritis dari penelitian ini . Menurut Casio,W.F., (2010), pengembangan karir merupakan salah satu faktor yang mempengaruhi peningkatan quality of work life pada anggota organisasi. Pengembangan karir yang jelas dan terbuka merupakan wahana untuk memotivasi karyawan agar dapat mengembangkan bakat dan kemampuannya. Untuk itu dapat ditempuh melalui penawaran kenaikan jabatan, memberi kesempatan mengikuti pelatihan dan penilaian karya.(Nawawi,2011). Dengan demikian, pengembangan karir memberikan kepastian hari depan karyawan sehingga akan berpengaruh positif terhadap quality of work life karyawan.

Hasil penelitian ini sejalan dengan penelitian sebelumnya yang dilakukan oleh Pratama,Yuda Muchti (2016). Kesimpulan dari penelitiannya adalah variabel dengan kategori baik adalah komunikasi, penyelesaian masalah, keterlibatan karyawan, dan rasa bangga terhadap institusi. Sedangkan kategori kurang baik adalah keamanan kerja,keselamatan lingkungan kerja, pengembangan karir, kompensasi dan fasilitas yang tersedia. Selain tiu, Rohayati, Teti. dkk (2020), menunjukkan hasil penelitiannya bahwa terdapat pengaruh langsung dan positif pemberdayaan terhadap pengembangan karir; terdapat pengaruh langsung dan positif pengembangan karir terhadap kualitas kehidupan kerja karyawan.

3) Pengaruh kompensasi dan pengembangan karir secara simultan terhadap quality of work life pada perawat rumah sakit di Kota Yogyakarta.

Hasil pengujian hipotesis ketiga $\left(\mathrm{H}_{3}\right)$ terbukti bahwa kompensasi dan pengembangan karir secara simultan berpengaruh signifikan terhadap quality of work life pada perawat rumah sakit di Kota Yogyakarta. Selain itu, hasil uji F didukung dengan nilai koefisien determinasi adjusted $\mathrm{R}^{2}$ sebesar 0,532 . Hal ini menunjukkan bahwa sumbangan pengaruh variabel kompensasi dan pengembangan karir terhadap quality of work life sebesar $53,2 \%$ sedangkan sisanya 46,8 \% dipengaruhi oleh variabel lain yang tidak diamati dalam penelitian ini

Lebih lanjut, $\mathrm{R}^{2}$ dan uji $\mathrm{F}$ bersifat sejalan/saling menggantikan (Gujarati 2012), artinya $\mathrm{R}^{2}$ diterima jika nilai $F$ hitung $>4$. Hasil $F$ hitung sebesar 53,2 (lebih besar dari 4) berarti model penelitian sudah tepat (fit), dalam arti pemilihan variabel penelitian sudah tepat. Dengan demikian, variasi variabel independen (kompensasi dan pengembangan karir) dalam menjelaskan variabel dependen ( quality of work life ), bisa diterima.

\section{SIMPULAN}

Berdasarkan analisis data, hasil penelitian, dan pembahasan diperoleh kesimpulan sebagai berikut

Kompensasi $\left(\mathrm{X}_{1}\right)$ berpengaruh positif dan signifikan terhadap Quality of Work Life (Y) pada perawat rumah sakit di Kota Yogyakarta. Hal ini dibuktikan dengan koefisien regresi kompensasi $\left(\mathrm{X}_{1}\right)$ sebesar 0,227 bertanda positif dengan nilai $\mathrm{t}$-hitung $=$ positif 2,701 $>$ nilai $\mathrm{t}$-tabel $=1,994$, serta nilai signifikansi $=0,009<$ nilai sig. $\alpha=$ 0,05. Dengan demikian, hipotesis pertama $\left(\mathrm{H}_{1}\right)$ dapat diterima. 
Pengembangan karir $\left(\mathrm{X}_{2}\right)$ berpengaruh positif dan signifikan terhadap Quality of Work Life (Y) pada perawat rumah sakit di Kota Yogyakarta.. Hal ini dibuktikan dengan koefisien regresi pengembangan karir $\left(\mathrm{X}_{2}\right)$ sebesar 0,546 bertanda positif dan nilai $\mathrm{t}$ hitung $=$ positif $5,746>$ nilai $\mathrm{t}$-tabel $=$ 1,994 , serta nilai signifikansi $=0,000$ $<$ nilai sig. $\alpha=0,05$. Dengan demikian, hipotesis kedua $\left(\mathrm{H}_{2}\right)$ dapat diterima

Kompensasi dan pengembangan karir secara simultan berpengaruh signifikan terhadap quality of work life pada perawat rumah sakit di Kota Yogyakarta. Hal ini dibuktikan dengan hasil F-hitung sebesar 43,1 > F-tabel sebesar 3,12 dan nilai signifikansi uji $\mathrm{F}$ sebesar $0,000<\alpha=0,05$.

\section{SARAN}

Berdasarkan kesimpulan tersebut diatas, maka disampaikan saran sebagai berikut :

- Untuk rumah sakit tipe D di wilayah Kota Yogyakarta

Sebaiknya pimpinan rumah sakit menerapkan filosofi quality of work life / kualitas kehidupan kerja dalam setiap proses kebijakan yang diputuskan, sehingga keputusan

\section{DAFTAR PUSTAKA}

Anisah. 2017. Evaluasi FaktorFaktor Yang Mempengaruhi Quality OfWork Life" (Studi Kasus PT.Pelabuhan Indonesia II Persero).

(Online).https://media.neliti.c om/media/publications/225458evaluasi- faktor-faktor-yangmempengaruhi-eadca6d1.pdf (diunduh 5 September 2020)

Bambang Wahyudi. 2002, Manajemen Sumber Daya Manusia, pimpinan merupakan sebuah respon atas apa yang menjadi keinginan dan harapan karyawan mereka, dengan cara menyatukan pandangan antara karyawan dan rumah sakit ke dalam tujuan yang sama.

Dalam hal pemberian kompensasi, perlu ditinjau kembali sistem dan struktur pemberian kompensasi langsung dan tidak langsung yang kompetitif dan dapat mensejahterakan karyawan sesuai dengan posisi/jabatannya di rumah sakit.

Dalam pengembangan karir, agar lebih diperhatikan adanya kepastian karir bagi karyawan/perawat agar karyawan/perawat termotivasi untuk terus berusaha meningkatkan kemampuan kerjanya terhadap organisas/rumah sakit sehingga tujuan rumah sakit mewujudkan mutu pelayanan kesehatan yang prima bisa tercapai.

- Untuk peneliti selanjutnya

Para peneliti lain dapat mengadakan penelitian lanjutan dengan variabel penelitian berbeda dari variabel yang digunakan dalam penelitian ini. Dengan demikian, penelitiannya akan menambah referensi empiris yang memadai dan dapat memperluas khazanah keilmuwan.

Edisi Pertama, Penerbit

SULITA, Bandung

Badan PPSDM Kesehatan, Informasi Kesehatan, Kementrian Kesehatan Republik

Indonesia.(Online)http://bppsd mk.kemkes.go.id/info_sdmk/info/dist ribusi_s dmk_rs_per_prov?prov $=34$ (diunduh 22 Agustus 2020)

Cascio, W. F. 2010. Managing Human Resources: Productivity, 
Quality of Work Life, Profits (eighth edition). New York: McGrawHill

Dinas Kesehatan DIY. (Online) https://dinkes.jogjaprov.go.id/berita/d etail/rumah- sakit-kerjasama-bpjsdaftar-rumah-sakit-yangbekerjasama-dengan-bjpskesehatan-di-diy (diunduh 22 Agustus 2020)

Edy, Sutrisno. 2016. Manajemen Sumber Daya Manusia, Kencana Prenada Media Group, Jakarta

Flippo, Edwin B. 2013. Personel Management (Manajemen Personalia), Edisi. VII Jilid II, Terjemahan Alponso S, Erlangga, Jakarta

Gujarati. 2012.Dasar-dasar ekonometrika buku 2 edisi 5. Salemba empat, Jakarta.

Handoko, T. Hani. 2014. Manajemen Personalia dan Sumber Daya Manusia. BPFE, Yogyakarta

Hasibuan, Malayu S.P. 2017. Manajemen Sumber Daya Manusia. PT.Bumi Aksara, Jakarta

Jogiyanto, H.M. 2016. Pedoman Survei Kuesioner: Mengembangkan Kuesioner, Mengatasi Bias dan Meningkatkan Respon. Yogyakarta: BPFE.

Luthans, Fred. 2006. Perilaku Organisasi. Edisi Sepuluh, PT. Andi: Yogyakarta

Marwansyah. 2014. Manajemen Sumber Daya Manusia. Edisi Dua. Cetakan keempat. Bandung: Alfabeta,CV
Marihot Tua Efendi Harianja, 2010. Manajemen Sumber Daya Manusia, Jakarta: Erlangga

Moekijat, 2010, Manajemen Sumber Daya Manusia, CV. Mandar Maju, Bandung

Moradi, T, Maghaminejad, F, \& Azizi-Fini, I. 2014. Quality of working life of nurses and its related factors. Nurs Midwifery Stud, 3(2): 3 . (Online)

https://www.ncbi.nlm.nih.gov/ pmc/articles/PMC4228533/ (diunduh $5 \quad$ September 2020)

Nawawi, 2011, Manajemen Sumber Daya Manusia: Untuk Bisnis Yang Kompetitif, Gajahmada University Press, Yogyakarta

PPNI. 2005. Standar Praktek Keperawatan Profesional. Jakarta

Potter, P.A, Perry, A.G.2005. Buku Ajar Fundamental Keperawatan : Konsep, Proses, dan Praktik.Edisi 4.Volume 2.Alih Bahasa : Renata Komalasari,dkk.Jakarta:EGC.

Porkiani, Masoud et.al, 2011. Relationship between the Quality of Work Life and Employees'

Aggression. Journal of American Science, 7(2). (Online)

http://www.jofamericanscienc e.org/journals/amsci/am0702/75_488 9am070 2_687_706.pdf (diunduh 5 September 2020)

Pratama,Yuda Muchti.2016.“Analisis Kualitas Kehidupan Kerja Perawat Pelaksana Di Rumah Sakit

Ptrtri Hijau Medan. (Online) http://garuda.ristekbrin.go.id/d ocuments/detail/569363 (diunduh 5 September 2020) 
Rohayati, Teti. Dkk 2020. Dampak Perubahan Pemberdayaan dan Pengembangan Karir

Terhadap Kualitas Kehidupan Kerja Pada PT Reasuransi Indonesia Utama (Persero)., (Online) http://journal.unj.ac.id/unj/index.php/ semnasps/article/view/16884/9169 (diunduh 6 September 2020)

Sevilla, Consuelo G. et. al. 2007. Research Methods. Rex Printing Company. Quezon City.

Simamora, Henry 2015, Manajemen Sumber Daya Manusia, cetakan kedua. Yogyakarta: YKPN
Sugiyono. 2016. Metode Penelitian Kuantitatif, Kualitatif, dan $R \& D$. Bandung: Alfabeta.

Sujarweni, V. Wiratna. 2014. Metode Penelitian: Lengkap, Praktis, dan Mudah Dipahami.

Yogyakarta: Pustaka Baru Press

Swansburg, R. C. (2000). Pengantar Kepemimpinan dan Manajemen Keperawatan.Jakarta : EGC terjemahan

Umar, Husein. 2013. Metode Penelitian untuk Skripsi dan Tesis. Jakarta: Rajawali 